Między wykluczeniem a dobrobytem. Refleksja nad społeczną myślą encykliki „Centesimus annus” Jana Pawła II, red. B. Bąk,

R. Kantor, M. Kluz, J. Młyński, Kraków 2017, s. 167-180.

DOI: http://dx.doi.org/10.15633/9788374386289.08

Ks. dr Jan Bartoszek

Sekretariat Komisji Duszpasterskiej Konferencji Episkopatu Polski

\title{
Demokracja w świetle wartości
}

Słowo „kryzys” jest dziś chyba najczęstszym określeniem pojawiającym się w sąsiedztwie słowa "demokracja”. Niemal codziennie słyszymy w telewizyjnych i prasowych doniesieniach o kryzysie demokracji. Rodzi się w związku z tym pytanie, czy jest to stan faktyczny, czy raczej wynik niewłaściwego rozumienia, czym jest demokracja i jakimi wartościami winna się charakteryzować. Trzeba mieć również świadomość, że jej rozumienie będzie przyjmować taki kształt, jaki dla danej grupy czy społeczności będzie korzystniejszy. Wtedy wyselekcjonowane pojęcie demokracji, stojące w opozycji do odniesienia zamierzonej korzyści, będzie rodzić w pewnych kręgach przekonanie o doświadczeniu kryzysu ustroju, jakim jest demokracja.

Jubileusz dwudziestopięciolecia encykliki Centesimus annus św. Jana Pawła II jest słuszną okazją, aby podjąć interdyscyplinarną refleksję nad tym dokumentem w kontekście obecnego stanu politycznego Europy i świata. Przedmiotem niniejszego artykułu nie będzie jednak analiza obowiązującego ustroju politycznego w Polsce, Europie czy na świecie, lecz ukazanie demokracji w świetle wartości, na które wskazuje Jan Paweł II we wspomnianej encyklice. 


\section{Kontekst nauki społecznej Kościoła}

Ustrój demokratyczny jako sposób rządzenia i sprawowania władzy nie jest efektem refleksji żadnego z chrześcijańskich teologów ani katolickich moderatorów życia społecznego. To stawia Kościół na łatwiejszej pozycji obserwatora i krytyka. Warto zaznaczyć, że Kościół prowadzi swoją działalność zbawczą w demokracji, a nawet pod demokratyczną strukturą państw, natomiast demokracja nie funkcjonuje w Kościele. Stąd też wynika jego ostrożność wobec tego typu sprawowania władzy. Jak zauważa Piotr Wróbel, nie bez znaczenia jest tu również postawa, jaką Kościół przyjmował w procesie kształtowania się ustrojów demokratycznych. Społeczeństwa, które zmierzały w tym kierunku, wyzwalały się spod rządów autorytarnych, np. monarchicznych, co ówczesnej nauce Kościoła na temat sprawowania rządów wydawało się mało korzystne ${ }^{1}$.

Trzeba jednak oddać sprawiedliwość i przyznać, że ostrożność Kościoła wobec demokracji oraz krytyka, z którą wychodził on ku niej, miała zazwyczaj charakter konstruktywny, była wyrazem autentycznej troski o człowieka i jego zasadniczy cel, jakim jest pełny rozwój.

Argumentem nie bez znaczenia uzasadniającym ostrożność Kościoła był również fakt, że kiedy państwa dążyły do tego ustroju, Kościół katolicki nie miał jeszcze wypracowanej własnej nauki społecznej. Katolicka nauka społeczna, jako systematyczne studium nad kwestią społeczną, zapoczątkowana została w XIX wieku w związku z niebezpieczeństwem płynącym ze strony komunizmu. Za jej początek przyjmuje się encyklikę papieża Leona XIII Rerum novarum z 1891 roku. Jan Paweł II wspomina o tym na samym początku encykliki Centesimus annus:

1 Por. P. Wróbel, Demokracja jako ustrój władzy państwa w encyklikach Jana Pawła II, Wrocław 2010, s. 10. 
niniejsza encyklika ma być dziękczynieniem Bogu, od którego zstępuje „każde dobro, jakie otrzymujemy, i wszelki dar doskonały" (Jk 1,17), za to, że posłużył się Dokumentem wydanym przed stu laty przez Stolicę Piotrową, aby w Kościele i w świecie dokonać tak wiele dobra i tyle zapalić świateł. Pragnę tu upamiętnić encyklikę Leona XIII, a zarazem encykliki i inne pisma moich Poprzedników, dzięki którym zachowała ona aktualność oraz siłę oddziaływania, i które złożyły się na to, co zostało nazwane „doktryną społeczną”, „nauczaniem społecznym” czy też „Magisterium społecznym” Kościoła ${ }^{2}$.

Tak więc od czasu Leona XIII ten dział teologii stał się prężną dyscypliną posiadającą swoje katedry na większości uczelni katolickich. Jej znaczenie podkreślali papieże, wystosowując do wiernych m.in. encykliki o tematyce społecznej ${ }^{3}$. Wśród nich ważne miejsce zajmują te ogłoszone przez Jana Pawła II: Laborem exercens (1981), Sollicitudo rei socialis (1987) i Centesimus annus (1991), która będzie stanowić główny punkt odniesienia w niniejszej refleksji. To właśnie w tym dokumencie papież, odnosząc się do społecznej nauki Kościoła, stwierdza, że

zasadność takiej formy obecności Kościoła pozwala mi dziś, po stu latach, wnieść wkład w proces kształtowania „chrześcijańskiej nauki społecznej”. „Nowa ewangelizacja”, której współczesny świat pilnie potrzebuje i której konieczność wielokrotnie podkreślałem, musi uczynić jednym ze swych istotnych elementów

2 Jan Paweł II, Encyklika Centesimus annus [dalej: CA], 2.

3 Pius XI, Encyklika Quadragesimo anno; Pius XII, Orędzie radiowe na uroczystość Zesłania Ducha Świętego 1941 (1 czerwca 1941), 195-205, „Acta Apostolicae Sedis" [dalej: AAS] 33 (1941); Jan XXIII, Encyklika Mater et Magistra o współczesnych przemianach społecznych w świetle nauki chrześcijańskiej; Paweł VI, List apostolski Octogesima adveniens. 
głoszenie nauki społecznej Kościoła, który zdolny jest dzisiaj, tak jak za czasów Leona XIII, wskazywać słuszną drogę i podejmować wielkie wyzwania współczesnej epoki, podczas gdy ideologie tracą wiarygodność. Tak jak wówczas, trzeba dziś powtórzyć, że nie ma prawdziwego rozwiązania "kwestii społecznej” poza Ewangelią i że „rzeczy nowe” mogą w niej odnaleźć swoją przestrzeń prawdy i odpowiedni fundament moralny ${ }^{4}$.

\section{Definicja demokracji}

W różnych słownikach można natrafić na różne definicje demokracji. Najmniej skomplikowaną, a zarazem najbardziej syntetyczną jest ta, która ujmuje dosłowną interpretację tego zagadnienia. Pojęcie „demokracja” składa się z dwóch greckich słów: demos - lud, kratein rządzić, co dosłownie znaczy „władza ludu”. Po raz pierwszy terminu tego użył prawdopodobnie grecki historyk Herodot (ok. 485-425 przed Chr.). Samo pojęcie demokracji nie jest czymś jednoznacznym. Ksiądz Waldemar Irek w artykule Wokół pojęcia demokracji wskazuje na trzy źródła trudności w precyzyjnym ukazaniu, czym ona jest. Pierwsze wynika $z$ tego, że jest to pojęcie bardzo stare, posiadające dwuipółtysiącletnią tradycję. W tym okresie „obrasta w konteksty i interpretacje i, by tak rzec, pęcznieje semantycznie, kumulując w sobie rozmaite znaczenia czy też znaczeniowe niuanse i nasączając się duchem epoki, w której jest używane" - pisze autor artyku$\nmid u^{5}$. Kolejna trudność jest związana z etymologią, ponieważ wiąże się z wieloznacznością słów demos oraz kratos. Pojęcia te ulegały i nadal ulegają różnym interpretacjom, co powoduje, że ich połączenie może tworzyć wręcz nieograniczoną liczbę kombinacji znaczeń. I wreszcie

4 CA 5.

5 W. Irek, Wokół pojęcia demokracji, w: „Wrocławski Przegląd Teologiczny” 1 (1993) nr 2, s. 58. 
trzecie źródło trudności, wydaje się, że najbardziej rzutujące na rozumienie pojęcia demokracji, wynika $\mathrm{z}$ faktu występowania tego pojęcia w dialogu politycznym. Nietrudno zauważyć, że kręgi polityczne relatywizują znaczenie tego pojęcia w zależności od zamierzonego celu politycznego. Ksiądz Irek napisał: „Wysunięcie twierdzenia, że ktoś jest «przeciwnikiem» lub «zwolennikiem» demokracji, oznacza często niewiele więcej niż to, że wysuwając takie stwierdzenie, ktoś broni swej władzy lub atakuje tych, którzy ją pełnią" ${ }^{6}$. W atmosferze politycznych emocji trudno o neutralizację czy obiektywizację znaczenia demokracji, która zostaje sprowadzona do rangi niewiele mówiącego sloganu przesiąkniętego sprzecznościami ${ }^{7}$.

Według Roberta A. Dahla za demokrację możemy uznać tylko ten ustrój, który zawiera w sobie „wszystkie instytucje polityczne niezbędne w demokracji" ${ }^{8}$. Zalicza do nich: 1) wybieranych przedstawicieli, 2) wolne, uczciwe i częste wybory, 3) wolność słowa, 4) różnorodność źródeł informacji, 5) wolność stowarzyszania się, 6) inkluzywne społeczeństwo ${ }^{9}$.

Warto w tym miejscu przywołać jeszcze innego współczesnego myśliciela politycznego, Giovanniego Sartoriego, który uważa, że gdy chodzi o demokrację, to „centralne znaczenie togo terminu nie jest ani arbitralne, ani nie wynika z czyjegoś projektu, gdyż jest osadzone w historii i z niej wynika" ${ }^{10}$. Z przytoczonego zdania można jasno wywnioskować, że dla Sartoriego definicja demokracji dojrzewa na przestrzeni dziejów, jest wrażliwa na doświadczenia ludzkości, a stąd ma ona dla nas znaczenie nie tyle krępujące, ile raczej wskazujące jej dynamiczny charakter. Jest to pojęcie, które jest swego

6 W. Irek, Wokół pojęcia demokracji, dz. cyt., s. 58.

7 Por. P. Wróbel, Demokracja..., dz. cyt., s. 123.

8 R. A. Dahl, O demokracji, przeł. M. Król, Kraków-Warszawa 2000, s. 96.

9 Por. R. A. Dahl, O demokracji, dz. cyt., s. 80.

10 G. Sartori, Teoria demokracji, przeł. P. Amsterdamski, D. Grinberg, Warszawa 1998, s. 325. 
rodzaju dziedzictwem, z którego musimy się uczyć, ale i na którym mamy budować coś nowego.

Za Encyklopedia nauczania społecznego Jana Pawła II można stwierdzić, że demokracja „to forma rządów politycznych zakładająca możliwość uczestnictwa (partycypacji) i opozycji (kontestacji) politycznej dużych kręgów społeczeństwa"11. Cenne uwagi na temat demokracji i jej rozumienia dodaje encyklika Jana Pawła II Centesimus annus ogłoszona 1 maja 1991 roku. Doceniając demokrację jako system, „który zapewnia udział obywateli w decyzjach politycznych i rządzonym gwarantuje możliwość wyboru oraz kontrolowania własnych rządów", Jan Paweł II przestrzega przed jej wykrzywieniem w stronę dyktatury „wąskich grup kierowniczych, które dla własnych korzyści albo celów ideologicznych przywłaszczają sobie władzę w państwie" ${ }^{12}$. W powyższych słowach słychać echo słów Platona, który bardzo mocno akcentował wagę właściwych warunków społecznych, przede wszystkim moralnych, dla realizacji demokracji autentycznej. Święty Jan Paweł II, określając warunki prawidłowego rozwoju systemu demokratycznego, napisał:

Autentyczna demokracja możliwa jest tylko w państwie prawnym i w oparciu o poprawną koncepcję osoby ludzkiej. Wymaga ona spełnienia koniecznych warunków, jakich wymaga promocja zarówno poszczególnych osób, przez wychowanie i formację w duchu prawdziwych ideałów, jak i „podmiotowości” społeczeństwa, przez tworzenie struktur uczestnictwa oraz współodpowiedzialności ${ }^{13}$.

11 „Ustrój demokratyczny pojawił się w Atenach pod koniec VI w. przed Chr., czyli dwa i pół tysiąca lat temu. Rozwijał się w V i VI w. przed Ch., tworząc pewien ideał społeczny, który miał odtąd towarzyszyć ludzkości przez długie wieki". A. Zwoliński, Demokracja, w: Encyklopedia nauczania społecznego Jana Pawła II, red. A. Zwoliński, Radom 2003, s. 101.

12 CA 46.

13 CA 46. 
Takie rozumienie demokracji wybrzmiewa również z artykułu: Nowe oblicza cezara. Kościót może i chce pomóc państwu ks. Janusza Królikowskiego. Pisze on, że

demokracja jako forma rządów traktująca naród jako suwerena decydującego o sprawach państwowych, a także określająca wartości, do których suweren ten winien się odwoływać, w ciągu dwóch wieków uchwaliła prawa i powołała do życia instytucje czyniące z państwa instrument osiągania dobra wspólnego, umożliwiające obywatelom sprawowanie kontroli nad organami władzy. Demokracja, mimo że stanowi formę rządów większości, ma chronić słuszne prawa mniejszości oraz czuwać nad bezinteresownością władzy w stosunku do wszystkich podmiotów, bez względu na zachodzące między nimi różnice: religijne, etniczne, ideologiczne itd. ${ }^{14}$.

Powyższe próby zdefiniowania demokracji, opisania jej genezy, kulturowych implikacji i historycznych zmian ujawniły pewną wewnętrzną dynamikę tego pojęcia, jego plastyczność, umiejętność dostosowywania się do lokalnych warunków, ale także do ideologicznych założeń różnych jego promotorów. Wiemy już, że za demokrację uznaje się formę ustroju politycznego państwa, gdzie obywatele mają możliwość sprawowania władzy, której źródłem jest wola większości. Ponadto może być ona synonimem samych tylko praw i wolności politycznych opartych na równości: po pierwsze wobec prawa, a po drugie - równości możliwości i szans.

Nie ulega wątpliwości, że o demokracji napisano i powiedziano wiele. Zjawisko to ciekawiło bowiem niegdyś starożytnych, tak jak dziś intryguje współczesnych. Z każdym nowym dziełem, czy

14 J. Królikowski, Nowe oblicza cezara. Kościół może i chce pomóc państwu, w: Wspólnota polityczna i Kościót, red. J. Królikowski, Tarnów 2016, s. 14 (Wspólnota Polityczna i Kościół, 1). 
to o charakterze ideowo-doktrynalnym, czy analityczno-opisowym, przybywa wyjaśnień, interpretacji, komentarzy, wykładni, a ściślej rzecz ujmując - teorii demokracji. Przez to wzrasta także liczba właściwości, cech, przymiotów i elementów ją charakteryzujących.

\section{Natura wartości - ontyczna zawartość}

Próba zdefiniowania wartości należy do bardzo trudnych zagadnień teoretycznych. Znany filozof Władysław Tatarkiewicz zastanawiał się wręcz, czy w ogóle wartości można zdefiniować ${ }^{15}$. Obejmują one normy, standardy zachowań, zaś w konsekwencji determinują, które cele i sposoby postępowania należy uznać za dobre, a które za złe. Wartości w sposób afektywny oddziałują na mobilizację emocjonalną jednostki, co oznacza, że działania podejmowane przez jednostkę można określić jako pozytywne lub negatywne.

Starożytni filozofowie używali na określenie wartości terminu agathon; w średniowieczu natomiast posługiwano się powszechnie słowem bonum. Oznaczało ono w pierwszej kolejności wartość, ale także cnotę, powinność, prawdę, dobro, piękno. W filozofii nowożytnej termin „wartość” upowszechnili pod koniec XIX wieku Fryderyk Nietzsche oraz Rudolf Hermann Lotze, którzy głosili hasło przewartościowania wszystkich wartości ${ }^{16}$.

Pojęcie wartości używane w języku potocznym, jak też w dyskursie filozoficznym oznacza coś, co jest cenne, godne pożądania, co stanowi cel ludzkich wysiłków. Często odwołujemy się do niego, oceniając czyjeś zachowanie, słuszność czyjejś wypowiedzi, szacując dzieło

15 Por. W. Tatarkiewicz, Dobro i oczywistość. Pisma etyczne, red. P. A. Smoczyński, Lublin 1989, s. 137.

16 Por. S. Kamiński, Jak uporzq̨dkować rozmaite koncepcje wartości, w: O wartościowaniu w badaniach literackich. Studia, red. S. Sawicki, W. Panas, Lublin 1986, s. 7-22 (Literatura w Kręgu Wartości). 
sztuki, klasyfikując dobra materialne, wyznaczając zakres obowiązków itd. Uznane powszechnie czy większościowo wartości stanowią podstawę ocen, norm i wzorów obowiązujących w danej kulturze.

Określenie statusu ontycznego wartości zmierza do zdefiniowania sposobu ich istnienia, powstawania i funkcjonowania. Rysują się tu trzy warianty:

- Istnienie wartości jest niezależne od człowieka, którego rola polega jedynie na ich odkrywaniu w świecie. Ten pogląd, nazwany w filozofii obiektywizmem, podzielali $\mathrm{m}$. in. Platon, św. Augustyn, św. Tomasz i Max Scheler.

- Drugi wariant widzi wartość jako coś, co zostało rzeczom nadane przez człowieka. To osoba w sposób subiektywny „wycenia” daną rzecz czy postawę, nadając jej określoną w hierarchii wartość. Reprezentantami tego stanowiska są m.in. starożytny filozof Epikur, oraz Tadeusz Kotarbiński.

- Inaczej ten problem widzą utylitaryści. W ich przekonaniu wartość uzyskuje status w zależności od tego, na ile dana rzecz czy postawa zaspokaja ludzkie potrzeby ${ }^{17}$.

W budowaniu hierarchii wartości niezbędny jest jakiś stały punkt odniesienia. Chodzi tu więc o hierarchię wartości, której osią jest sam człowiek - to tzw. antropocentryzm aksjologiczny, który w sposób skrajny głosił Protagoras z Abdery (ok. 480 - ok. 410 przed Chr.), twierdzący, że człowiek jest miarą wszechrzeczy ${ }^{18}$. Należy tu także przywołać teocentryzm aksjologiczny, gdzie o charakterze wartości decyduje Stwórca.

W związku z powyższym pojawiają się następujące koncepcje: normy moralne pochodzą od Boga i są zapisane w Piśmie Świętym; mają swe źródło w prawie naturalnym; wywodzą się z mniej lub bardziej odległej tradycji; są wytworem ludzkiej kreatywności. Nie

17 Por. P. Wróbel, Demokracja..., dz. cyt., s. 194.

18 Por. G. Reale, Historia filozofii starożytnej, t, I, Od poczq̨tków do Sokratesa, przeł. E. I. Zieliński, Lublin 1994, s. 247nn. 
zawsze te koncepcje są traktowane hermetycznie i wrogo wobec siebie. To, że za ostateczne źródło norm moralnych uznaje się Boga, nie oznacza, iż całkowicie odrzuca się ludzką ingerencję w ich obecny kształt. Jak zauważa P. Wróbel:

Również pogląd na prawnonaturalne pochodzenie norm nie sprzeciwia się poglądowi o ich kulturowej i historycznej modyfikacji. Po drugie, istnieje pewna „naturalna” bliskość owych koncepcji: objawieniowe pochodzenie norm moralnych nakłada się na poszukiwanie ich w naturze stworzenia, a uznanie, iż mają one za swe źródło jedynie ludzki, autonomiczny rozum wiąże się z poglądem z poglądem na ich historyczno-kulturowe ewaluowanie i zsynchronizowanie $\mathrm{z}$ ewolucją samego rozumu ${ }^{19}$.

Po tych krótkich rozważaniach dotyczących zrozumienia, czym jest wartość oraz jakie filozoficzne zawirowania towarzyszą jej rozpoznawaniu i pochodzeniu, możemy przejść do zasadniczego tematu niniejszego artykułu - demokracji w świetle wartości.

\section{Aksjologia demokracji}

Wizja człowieka determinuje przyjmowany porządek społeczny. Karol Wojtyła, mając tego świadomość, przeniósł wypracowaną przez siebie w tzw. okresie krakowsko-lubelskim antropologię na grunt nauki społecznej Kościoła kształtowanej w okresie swego pontyfikatu. Człowiek - osoba - w antropologii Jana Pawła II jest podmiotem moralnym, a więc otoczony nicią zobowiązania i odpowiedzialności za otaczający go świat. Choć na mocy wyjątkowości aktu jego stworzenia przysługuje mu prymat w stosunku do innych stworzeń, to

19 P. Wróbel, Demokracja..., dz. cyt., s. 196. 
jednak nie uwalnia go to od troski o to, co zostało powierzone jego opiece. W Redemptor hominis papież Jana Paweł II nakreśla hierarchię wartości, która winna być zachowywana w świecie widzialnym, powierzonym człowiekowi przez Stwórcę, która

leży w pierwszeństwie etyki nad techniką, leży w prymacie osoby w stosunku do rzeczy, leży w pierwszeństwie ducha wobec materii. I dlatego też trzeba gruntownie śledzić wszystkie procesy rozwoju współczesnego, trzeba niejako prześwietlać poszczególne jego etapy pod tym właśnie kątem widzenia. Chodzi o rozwój osób, a nie tylko o mnożenie rzeczy, którymi osoby mogą się posługiwać $^{20}$.

Przytoczone powyżej priorytety: osoby nad rzeczą, etyki nad techniką, ducha nad materią, a także (dodane potem) miłosierdzia nad sprawiedliwością ${ }^{21}$ i pracy nad kapitałem ${ }^{22}$, tworzą trzon papieskiego personalizmu. Przebija przez nie też to, co można nazwać papieskim postrzeganiem godności osoby jako wartości fundamentalnej. Te właśnie priorytety są stałym punktem odniesienia w podejmowanych w encyklice Centesimus annus kwestiach społecznych, które stanowią pogłębienie „kwestii robotniczej” omówionej w encyklice Rerum novarum Leona XIII.

Dla Jana Pawła II, podobnie jak i dla całego społecznego nauczania Kościoła, wartością fundamentalną jest głoszenie poprawnej koncepcji osoby ludzkiej: „jej niepowtarzalnej wartości, płynącej stąd, że człowiek jest «jedynym na ziemi stworzeniem, którego Bóg chciał dla niego samego». Uczynił go na swój obraz i podobieństwo (por. Rdz 1,26), obdarzając niezrównaną godnością" ${ }^{23}$. Niemożliwa

20 Jan Paweł II, Encyklika Redemptor hominis, 16.

21 Por. n Paweł II, Encyklika Dives in misericordia o miłosierdziu Bożym, 4.

22 Por. Jan Paweł II, Encyklika Laborem exercens o pracy ludzkiej, 12.

23 CA 11. 
jest więc demokracja bez budowania sprawiedliwego porządku społecznego, który uwzględniałby tę prawdę o człowieku i jego naturze.

Przedstawiając pozytywną naukę o człowieku, Jan Paweł II zwraca uwagę na indywidualny, ale i społeczny charakter jego natury. Szczególnie ten drugi element wydaje się dzisiaj poważnie zagrożony, dlatego papież domaga się właściwego jego rozumienia i podporządkowania prawdziwej naturze ludzkiej:

Człowiek otrzymuje od Boga swą istotną godność, a wraz z nią zdolność wznoszenia się ponad wszelki porządek społeczny w dążeniu do prawdy i dobra. Jest on jednak również uwarunkowany strukturą społeczną, w której żyje, otrzymanym wychowaniem i środowiskiem. Elementy te mogą ułatwiać albo utrudniać życie według prawdy. Decyzje więc, dzięki którym powstaje jakieś ludzkie środowisko, mogą tworzyć specyficzne struktury grzechu, przeszkadzając w pełnej ludzkiej realizacji tym, którzy są przez te struktury w rozmaity sposób uciskani. Burzenie takich struktur i zastępowanie ich bardziej autentycznymi formami współżycia jest zadaniem wymagającym odwagi i cierpliwości ${ }^{24}$.

Podstawową wartością „ekologii ludzkiej” jest rodzina ${ }^{25}$. W niej człowiek uczy się wrażliwości na prawdę i dobro, poznaje, czym jest miłość oraz jak ją okazywać i przyjmować. Dla Ojca Świętego bardzo ważnym pojęciem opisującym relacje międzyludzkie jest dar. W encyklice Centesimus annus pisze, iż: „człowiek (...) staje się naprawdę sobą poprzez wolny dar z siebie samego; dar ten jest możliwy dzięki podstawowej «zdolności transcendencji» osoby ludzkiej” ${ }^{26}$. To właśnie rodzina jest tym środowiskiem, gdzie takie rozumienie daru z siebie może we właściwy sposób rozkwitać. Dla Jana Pawła II rodzina

24 CA 38.

25 Por. CA 39.

26 CA 41. 
jest przede wszystkim „sanktuarium życia”, w którym człowiek włącza się w boskie dzieło stworzenia, ale także wychowania i dojrzewania. Dlatego też rodzina winna być wartością dla demokratycznego państwa, które powinno jej zapewnić zarówno prawne, jak i infrastrukturalne środki ochrony i rozwoju życia ludzkiego.

W omawianej encyklice na osobny komentarz zasługuje nauka o wolności człowieka. Papież umieszcza ją głównie w kontekście różnych programów polityczno-gospodarczych, wskazując na niebezpieczeństwa, jakie ze sobą niosą. Podejmując społeczną myśl Leona XIII i jego krytykę egoistycznego kapitalizmu, Jan Paweł II stwierdza, iż ideologia ta skażona była podstawowym błędem, który „kryje się w koncepcji ludzkiej wolności oderwanej od posłuszeństwa prawdzie, a zatem również od obowiązku poszanowania praw innych ludzi. Treścią wolności staje się wówczas miłość samego siebie posunięta aż do wzgardzenia Bogiem i bliźnim, miłość, która prowadzi do bezgranicznej afirmacji własnej korzyści i nie daje się ograniczyć żadnymi nakazami sprawiedliwości" ${ }^{27}$. Konsekwencją tego błędu były wydarzenia w Europie między 1914 a 1945 rokiem, kiedy to doszły do głosu ideologie oparte na nacjonalizmie, walce klas, militaryzmie i totalitaryzmie. Dzisiaj ofiary tego błędu liczone są w dziesiątkach milionów.

Wolność leży w naturze człowieka. Jest jego integralną częścią, wyróżniającą go spośród innych bytów. Człowiek jest także stworzony do wolności. Oznacza to, że każde jej niesłuszne ograniczenie jest nieetyczne i na dłuższą metę niemożliwe do utrzymania. Ale „człowiek stworzony do wolności nosi w sobie ranę grzechu pierworodnego, który stale pociąga go ku złu i sprawia, że potrzebuje on odkupienia” 28 .

Stąd też papież w encyklice przypomina, iż „wolność (...) w pełni jest dowartościowana jedynie poprzez przyjęcie prawdy: w świecie 
bez prawdy wolność traci swoją treść, a człowiek zostaje wystawiony na pastwę namiętności i uwarunkowań jawnych lub ukrytych" 29 . Prawda ta odnosi się także, a może przede wszystkim, do budowania demokracji na wartościach, których trwałym i nieusuwalnym jądrem jest właściwie rozumiana koncepcja osoby ludzkiej, odsłaniająca jego godność, ale i ograniczoność. Wolność nieopisana prawami zbudowanymi na prawdzie wcześniej czy później prowadzi bowiem do nowego zniewolenia, czy to jednostek, czy całych społeczeństw.

Dokonując podsumowania powyższych treści, warto sobie zadać zasadnicze pytanie: czy demokracja potrzebuje wartości? Czym w zasadzie te wartości są dla demokracji? Czy czegoś bronią? Może coś gwarantują?

Bez wątpienia każda doktryna potrzebuje silnych fundamentów w postaci wzniosłych przymiotów. Dla liberalizmu naczelną wartością jest wolność. Konserwatyzm cechuje z kolei skupienie się na ideach tradycji, religii i autorytetów. Nacjonalizm zaś wychwala naród, a jego podstawą jest patriotyzm. Z tego punktu widzenia niewątpliwie omawiana w tym artykule demokracja w myśl encykliki winna opierać się na wartościach takich jak godność osoby, rodzina, wolność i prawda.

Czy konieczne jest czynne dbanie o wartości demokratyczne w praktyce? Czy może są one czysto teoretyczne i można o nich zapomnieć w realizowaniu porządku demokratycznego? Wydaje się, że właściwą odpowiedź ponownie przynosi encyklika Centesimus annus, w której papież Jan Paweł II napisał: „Historia uczy, że demokracja bez wartości łatwo się przemienia w jawny lub zakamuflowany totalitaryzm" 30 . 